\title{
Stratospheric ozone in the post-CFC era
}

\author{
F. Li ${ }^{1}$, R. S. Stolarski ${ }^{2}$, and P. A. Newman ${ }^{2}$ \\ ${ }^{1}$ GEST, University of Maryland, Baltimore County, Baltimore, MD, USA \\ ${ }^{2}$ Atmospheric Chemistry and Dynamics Branch, NASA GSFC, Greenbelt, MD, USA \\ Received: 19 September 2008 - Published in Atmos. Chem. Phys. Discuss.: 3 December 2008 \\ Revised: 26 February 2009 - Accepted: 10 March 2009 - Published: 24 March 2009
}

\begin{abstract}
Vertical and latitudinal changes in the stratospheric ozone in the post-chlorofluorocarbon (CFC) era are investigated using simulations of the recent past and the 21st century with a coupled chemistry-climate model. Model results reveal that, in the 2060s when the stratospheric halogen loading is projected to return to its 1980 values, the extratropical column ozone is significantly higher than that in 1975-1984, but the tropical column ozone does not recover to 1980 values. Upper and lower stratospheric ozone changes in the post-CFC era have very different patterns. Above $15 \mathrm{hPa}$ ozone increases almost latitudinally uniformly by 6 Dobson Unit (DU), whereas below $15 \mathrm{hPa}$ ozone decreases in the tropics by $8 \mathrm{DU}$ and increases in the extratropics by up to $16 \mathrm{DU}$. The upper stratospheric ozone increase is a photochemical response to greenhouse gas induced strong cooling, and the lower stratospheric ozone changes are consistent with enhanced mean advective transport due to a stronger Brewer-Dobson circulation. The model results suggest that the strengthening of the Brewer-Dobson circulation plays a crucial role in ozone recovery and ozone distributions in the post-CFC era.
\end{abstract}

\section{Introduction}

The stratospheric ozone layer is expected to recover to pre1980 levels in the middle of the 21st century with the projected decline of the stratospheric halogen loading (WMO, 2007). Coupled chemistry-climate model (CCM) simulations have found that the recovery of the stratospheric ozone and halogen to 1980 levels will not happen at the same time, because ozone recovery is strongly dependent on temperature and transport, which in the middle 21 st century, are

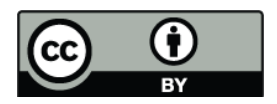

Correspondence to: $\mathrm{F} . \mathrm{Li}$

(Feng.Li@nasa.gov) significant different from those in the 1980s (Eyring et al., 2007). Increased greenhouse gases (GHGs) will cool the stratosphere, leading to an increase in the upper stratospheric ozone due to the strong temperature dependence of the gasphase photochemical ozone loss reactions (Barnett et al., 1975; Jonsson et al., 2004). Additionally model simulations project that the Brewer-Dobson circulation will speed up with the increase of GHGs (e.g., Butchart et al., 2006). An accelerated Brewer-Dobson circulation transports more ozone from tropics to the mid-high latitudes and could delay ozone recovery in the tropics and advance ozone recovery in the extratropics (Austin and Wilson, 2006; Shepherd, 2008; Waugh et al., 2009).

An important aspect of ozone recovery is the vertical and latitudinal characteristics of ozone distributions in the post-chlorofluorocarbon (CFC) era, which has not been extensively investigated by previous work. Changes in temperature and transport have very different effects on ozone abundance in the upper and lower stratosphere because of the ozone photochemical lifetime differences in the two regions (Shepherd, 2008). The acceleration of the BrewerDobson circulation will change the latitudinal distribution of ozone by bringing more ozone-poor air into the tropical lower stratosphere and more ozone-rich air into the midhigh latitudes (Jiang et al., 2007). Detailed examinations of the vertical and latitudinal structure of ozone changes can help us to understand how the ozone layer is affected by climate change. Shepherd (2008) investigated the effects of climate change on ozone recovery using Canadian Middle Atmosphere Model (CMAM) simulations and found a "superrecovery" of the extra-tropical ozone and "sub-recovery" of the tropical ozone at the end of the 21st century with respect to 1960 values. Shepherd (2008) also noted cancellation between upper stratospheric ozone increase and lower stratospheric ozone decrease in a global sense. Based on the vertical and latitudinal structure of ozone changes, Shepherd (2008) suggested that lower stratospheric ozone changes

Published by Copernicus Publications on behalf of the European Geosciences Union. 
induced by a strengthened Brewer-Dobson circulation have a significant role in ozone recovery.

This paper investigates the impacts of climate change on ozone recovery using simulations of the recent past (late 20th century) and future (21st century) from the Goddard Earth Observing System (GEOS) CCM (Pawson et al., 2008). We study vertical and latitudinal ozone changes after the stratospheric halogen loading returns to 1980 levels. Decadal differences in the stratospheric ozone between 2060s and 19751984 are examined when the halogen amounts are nearly the same during these two decades. These differences are interpreted as mainly caused by climate change and are consistent with an increased Brewer-Dobson circulation in the lower stratosphere and strong cooling in the upper stratosphere.

\section{Model simulations}

This study uses past and future climate simulations from GEOSCCM Version 1, which is based on the GEOS-4 General Circulation Model. It includes a comprehensive stratospheric chemistry scheme that is coupled with the physical processes through the radiation code. The model has a horizontal resolution of $2^{\circ} \times 2.5^{\circ}$ and 55 vertical levels with a model top at $0.01 \mathrm{hPa}$. A detailed description of GEOSCCM Version 1 is given by Pawson et al. (2008).

A number of time-slice and time-dependent simulations of the recent past (1951-2005) and future (2001-2099) have been performed using the GEOSCCM Version 1. Model results have been evaluated and analyzed to address several different scientific questions (Eyring et al., 2006, 2007; Pawson et al., 2008; Perlwitz et al., 2008). Overall, model simulations of the recent past agree reasonably well with observations in stratospheric dynamics, transport, and ozone distribution and depletion (Eyring et al., 2006, 2007; Pawson et al., 2008).

For this study, two sets of simulations for the period 1975-2070 are used. The first set is forced with standard scenarios of GHGs and ozone-depleting substances (ODSs) (Eyring et al., 2006). Sea-surface temperature and sea-ice amounts (SSTs) are from integrations of the NCAR Community Climate System Model (CCSM). The external forcings used for the second simulation differ from those in the first one in that, 1. the halogen concentrations are fixed at 1960 levels, and 2. SSTs are switched from observations to NCAR CCSM data in 2001. These two sets of simulations are referred to as FREF (future reference runs) and $\mathrm{Cl60}$ (fixed 1960 halogen amount simulations).

\section{Model results}

The WMO Scientific Assessment of Ozone Depletion report (2007) estimates that full recovery of ozone will likely occur when the Equivalent Effective Stratospheric Chlorine (EESC) returns to pre-1980 levels. EESC is a measure to

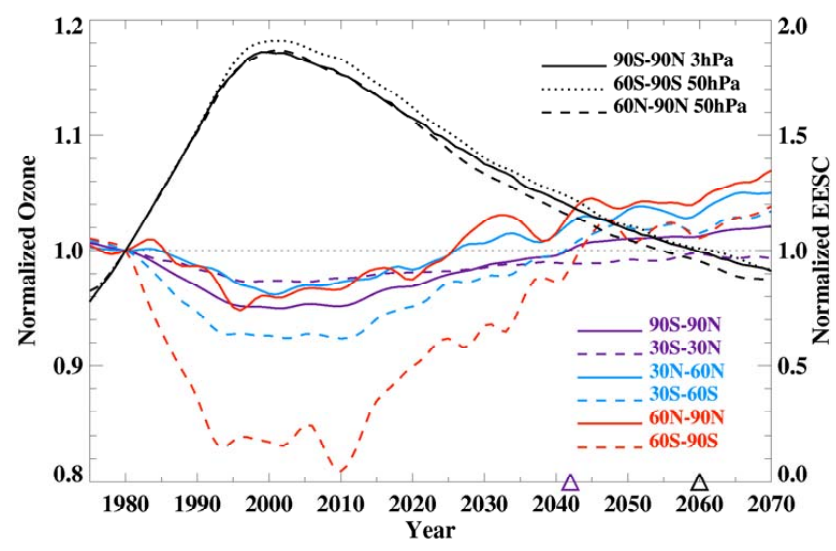

Fig. 1. Evolution of normalized annual mean EESC (black lines, right axis) and column ozone (color lines, left axis) in different regions. EESC and column ozone are normalized relative to their 1980 values. The curves are smoothed using a Gaussian filter with a half amplitude response at 8.5 years. The purple and black triangles indicate the dates of recovery of global mean column ozone and $3 \mathrm{hPa}$ EESC to 1980 values, respectively.

quantify the effects of chlorine and bromine containing halogens on ozone depletion in the stratosphere (Newman et al., 2007). Evolution of EESC has the largest effect on ozone in the upper stratosphere and polar lower stratosphere. Figure 1 shows that EESC in these regions returns to 1980 values by the early 2060s in FREF. EESC in the tropics and mid-latitudes reach 1980 levels during the 2040s (not shown). Figure 1 also shows that, except in the tropics, the column ozone returns to 1980 values much earlier than the EESC does. The earliest ozone recovery occurs in the Northern Hemisphere (NH) mid-latitudes and the Arctic at about 2025. Recovery of the global, Southern Hemisphere (SH) mid-latitude, and Antarctic column ozone happens between 2040-2045. In the early 2060s when the EESC returns to 1980 values, ozone amounts in these regions are higher than their 1980 values, indicating a "super recovery". The tropical ozone is an exception. It is least affected by EESC with a maximum depletion of less than $3 \%$, but it never recovers to 1980 values during the simulations.

The ozone evolution from 1980-2070 in FREF is similar to many other CCM projections (Eyring et al., 2007). The different recovery dates between ozone and EESC strongly suggest that GHG increases have a significant impact on ozone recovery. The focus of this study is the effects of climate change on the vertical and latitudinal ozone changes. In order to separate the contributions to ozone changes from ODSs and GHGs, we examine the decadal differences in ozone between 1975-1984 and 2060-2069. In FREF simulations, EESC has recovered to pre-1980 values in the 2060s. The differences in EESC between 2060-2069 and $1975-1984$ are within $10 \%$ in regions that are mostly affected by ODSs, i.e., the upper stratosphere and polar regions. 

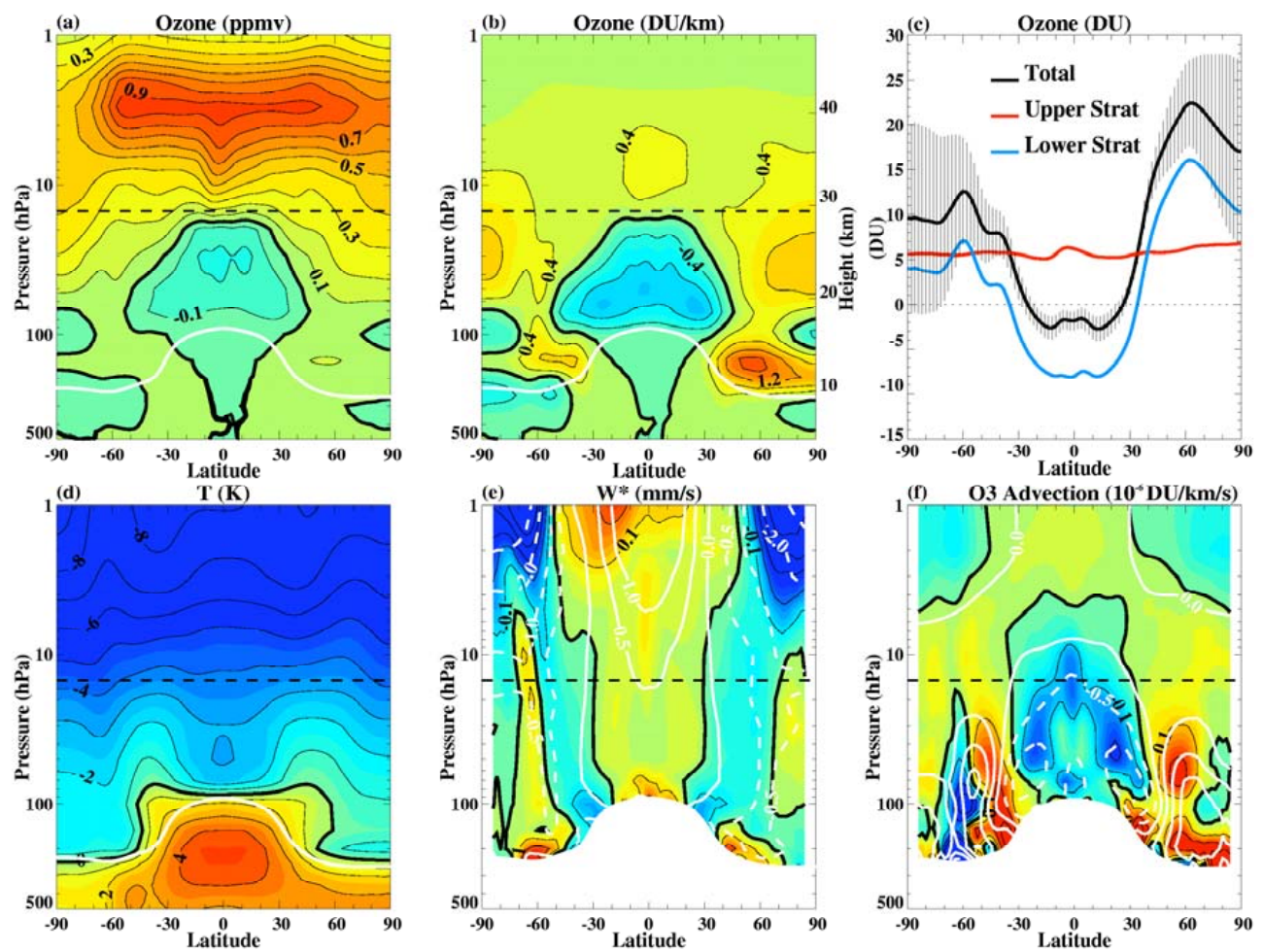

Fig. 2. Decadal differences between 2060-2069 and 1975-1984 from FREF. (a) Ozone concentrations in ppmv (contour interval: 0.1 ppmv). (b) Ozone concentrations in DU/km (contour interval: $0.4 \mathrm{DU} / \mathrm{km}$ ). (c) Total column ozone and contributions from the upper (above $15 \mathrm{hPa}$ ) and lower (below $15 \mathrm{hPa}$ ) stratosphere. The black vertical lines indicate $2 \sigma$ uncertainties of the decadal difference in the total column ozone. (d) Temperature (contour interval: $1 \mathrm{~K}$ ). (e) The vertical residual velocity $\bar{w}^{*}$ (contour interval: $0.1 \mathrm{~mm} / \mathrm{s}$ ). The white contours are $1975-$ 1984 mean (contour interval: $0.5 \mathrm{~mm} / \mathrm{s})$. (f) The mean ozone advection $-\left(\bar{w}^{*} \frac{\partial\left[\overline{\mathrm{O}}_{3}\right]}{\partial z}+\bar{v}^{*} \frac{\partial\left[\overline{\mathrm{O}}_{3}\right]}{\partial y}\right)$ (contour interval: $\left.0.1 \times 10^{-6} \mathrm{DU} / \mathrm{km} / \mathrm{s}\right)$. The white contours are 1975-1984 mean (contour interval: $0.5 \times 10^{-6} \mathrm{DU} / \mathrm{km} / \mathrm{s}$ ). The white lines in panels (a), (b) and (d) are decadal mean tropopause for 1975-1984. Panels (e) and (f) only show changes in the stratosphere.

Therefore we interpret decadal differences in the stratospheric ozone and dynamics between these two decades are mostly due to GHG increase.

Ozone changes between 2060-2069 and 1975-1984 have very different features in the upper and lower stratosphere (Fig. 2a). Above about $15 \mathrm{hPa}$, ozone concentrations increase everywhere and this increase is almost latitudinally uniform in the sub-polar region. Below $15 \mathrm{hPa}$, ozone concentrations decrease in the tropics and increase in most of the extratropics. Lower stratospheric ozone changes stand out when the changes are plotted in Dobson Unit (DU)/km, showing a near hemispheric symmetric pattern (Fig. 2b). However, there are quantitative inter-hemispheric differences. For example, the bell-shaped negative region in the tropics extends further into the $\mathrm{SH}$ mid-latitudes and the lower stratospheric ozone increase at $60^{\circ} \mathrm{N}$ is larger than at $60^{\circ} \mathrm{S}$.

Figure $2 \mathrm{c}$ shows the column ozone changes and the contributions from above and below $15 \mathrm{hPa}$ (hereafter referred as upper and lower stratosphere, respectively). Total column ozone changes are marked by increases in the extratropics and small decreases in the tropics. These differences are statistically significant except in the southern high latitudes. The largest increase occurs around $60^{\circ}$ in both hemispheres, with peaks of $23 \mathrm{DU}(6 \%)$ in the $\mathrm{NH}$ and $13 \mathrm{DU}$ $(3 \%)$ in the SH. The latitudinal structure of column ozone is almost solely due to changes in the lower stratosphere, where ozone decreases by $8 \mathrm{DU}$ in the tropics, and increases by up to 16 and $7 \mathrm{DU}$ in the northern and southern extratropics, respectively. The uniform increase of upper stratospheric ozone ( $\sim 6 \mathrm{DU})$ also makes a significant contribution to the total column ozone changes, especially in the tropics and $\mathrm{SH}$. Interestingly, the opposite ozone changes in the tropical and extratropical lower stratosphere nearly cancel each other, resulting in an area-weighted global-mean lower stratospheric ozone change of $-0.4 \mathrm{DU}$. Therefore the global-mean total column ozone increase (5.3 DU) is attributed to increases in the upper stratospheric ozone (5.7 DU).

The very different structures in the upper and lower stratospheric ozone changes strongly indicate different ozone control mechanisms in the two regions. Intuitively, the increase in the upper stratospheric ozone suggests a chemical response to GHG cooling, whereas the unique 
latitudinal structure of the lower stratospheric ozone changes indicates an acceleration of the Brewer-Dobson circulation. We now examine changes in temperature and the BrewerDobson circulation between 2060-2069 and 1975-1984, and discuss whether these changes are consistent with the ozone changes.

Increased $\mathrm{CO}_{2}$ results in a warming in the troposphere and cooling in the stratosphere (Fig. 2d). The cooling in the stratosphere increases with height, reaching a value of $8 \mathrm{~K}$ (or about $1 \mathrm{~K} /$ decade) near the stratopause. A reverse relationship between ozone and temperature in the upper stratosphere has long been known, which is due to temperature dependence of the gas-phase photochemical ozone loss reactions, particularly in the Chapman cycle $\mathrm{O}+\mathrm{O}_{3} \rightarrow 2 \mathrm{O}_{2}$ and in the reaction $\mathrm{O}+\mathrm{O}_{2}+\mathrm{M} \rightarrow \mathrm{O}_{3}+\mathrm{M}$ that determines atomic oxygen concentrations (Rosenfield et al., 2002; Jonsson et al., 2004). Therefore GHG increases lead to slowing of ozone loss reactions and ozone increase in the upper stratosphere.

Changes of the lower stratospheric ozone appear to support an enhanced advection. In a simplified view, the stratospheric transport consists of a mean advection by the BrewerDobson circulation and horizontal mixing. The horizontal mixing in CCMs is very difficult to be quantitatively diagnosed as an underlying general theory is still missing, but we can assess changes in the mean transport by examining the residual circulation. Figure $2 \mathrm{e}$ shows an overall accelerated Brewer-Dobson circulation in the 2060s compared with 1975-1984. In the tropics, upwelling increases from the tropopause to the stratopause. At $70 \mathrm{hPa}$ between $20^{\circ} \mathrm{S}$ and $20^{\circ} \mathrm{N}$, the magnitude of increase is $26 \%$, or about $3 \%$ per decade, which is within the range of tropical mass flux increase reported by other modeling groups (Butchart et al., 2006). The enhanced tropical upward mass flux is balanced by an increase in the extratropical downwelling, although it should be noted that there exist regions where downwelling actually becomes weaker. Most notably these regions include the Arctic lower stratosphere $\left(70^{\circ} \mathrm{N}-90^{\circ} \mathrm{N}, 100-10 \mathrm{hPa}\right)$ and a narrow band centered at $60^{\circ} \mathrm{S}$ from 100 to about $5 \mathrm{hPa}$.

Figure $2 \mathrm{f}$ shows that the accelerated Brewer-Dobson circulation enhances the mean advective ozone transport $-\left(\bar{w}^{*} \frac{\partial\left[\overline{\mathrm{O}}_{3}\right]}{\partial z}+\bar{v}^{*} \frac{\partial\left[\overline{\mathrm{O}}_{3}\right]}{\partial y}\right)$, where $\left[\overline{\mathrm{O}}_{3}\right]$ is the zonal mean ozone volume mixing ratio, and $\bar{v}^{*}$ and $\bar{w}^{*}$ are the meridional and vertical residual velocity. Because the vertical ozone gradient changes sign from positive to negative around $10 \mathrm{hPa}$ (ozone concentrations peak around $10 \mathrm{hPa}$ ), enhanced upwelling in the tropics produces larger negative ozone tendency in the lower stratosphere and larger positive tendency in the upper stratosphere. In the middle and high latitudes, accelerated downwelling results in stronger negative ozone tendency in the upper stratosphere, and larger positive ozone tendency in the lower stratosphere except in a band near $60^{\circ} \mathrm{S}$ and the Arctic lower stratosphere.

Comparing Fig. $2 f$ with Fig. $2 b$ reveals that changes in ozone abundance and the mean advective ozone transport have a qualitatively similar pattern in the lower stratosphere, suggesting that lower stratospheric ozone changes are controlled mainly by changes in the mean advection. Interestingly, mean transport also shows inter-hemispheric differences in the mid-high latitudes in the lower stratosphere. It is likely that the reduced ozone advection in $50^{\circ} \mathrm{S}-70^{\circ} \mathrm{S}$ is responsible for a smaller $\mathrm{SH}$ ozone increase in this region. Note that the details of the lower stratosphere changes between the mean transport and ozone abundance are quite different. Overall, changes in ozone are smoother and have a smaller latitudinal gradient compared with changes in the mean transport. These differences are most likely due to horizontal mixing which acts to smooth tracer concentrations across latitudes.

Strengthening of the Brewer-Dobson circulation is a robust response to GHG increase in model simulations (Butchart et al., 2006; Li et al., 2008; Garcia and Randel, 2008; McLandress and Shepherd, 2009; Oman et al., 2009). Butchart and Scaife (2001) found that an accelerated BrewerDobson circulation could advance ozone recovery indirectly via changes of the CFC lifetime. The direct impact of an enhanced Brewer-Dobson circulation on ozone is investigated by Jiang et al. (2007) using a two-dimensional chemistry and transport model. They found that, when the $100 \mathrm{hPa}$ upwelling mass flux increases by $10 \%$, total ozone decreases by $4 \mathrm{DU}$ in the tropics, and increases by 7 and 3.5 DU in the northern and southern high latitudes, respectively. The latitudinal structure and the relative magnitude of ozone changes in Jiang et al. (2007) (their Fig. 3) are in good agreement with those of the lower stratospheric ozone changes in FREF. These similarities support our argument that lower stratospheric ozone changes can be largely attributed to an enhanced mean ozone transport.

In the upper stratosphere, changes in ozone abundance and mean ozone transport have differing patterns. The mean advection shows increases in the tropics and decreases in the extratropics, whereas ozone displays a nearly latitudinal uniform increase. The opposite changes between ozone concentrations and mean advection in the extratropical upper stratosphere indicate that long-term ozone change is not determined by transport in this region, where ozone is in photochemical equilibrium (Ko et al., 1989). One may also notice that the regions of negative advection in the tropics, where mixing is weak, extend to $5 \mathrm{hPa}$ (Fig. 2f), but ozone decrease is confined below $15 \mathrm{hPa}$ (Fig. 2b). We think this difference suggests a shift from transport control to chemical control of ozone across $10 \mathrm{hPa}$. We estimated the lifetimes for mean ozone advection $\tau_{\text {adv }}$ and photochemical ozone loss $\tau_{\text {loss }}, \tau_{\text {adv }}^{-1}=-\frac{1}{\left[\overline{\mathrm{O}}_{3}\right]}\left(\bar{w}^{*} \frac{\partial\left[\overline{\mathrm{O}}_{3}\right]}{\partial z}+\bar{v}^{*} \frac{\partial\left[\overline{\mathrm{O}}_{3}\right]}{\partial y}\right)$ and $\tau_{\text {loss }}^{-1}=-\bar{L}$, where $\bar{L}$ is the zonal mean ozone loss rate. The chemical loss lifetime decreases very sharply with height. In the tropics $\left(20^{\circ} \mathrm{S}-20^{\circ} \mathrm{N}\right)$, the chemical loss lifetime is more than 100 times longer than the advective lifetime at $70 \mathrm{hPa}$, and becomes comparable to the advective lifetime at 20 and $30 \mathrm{hPa}$ 

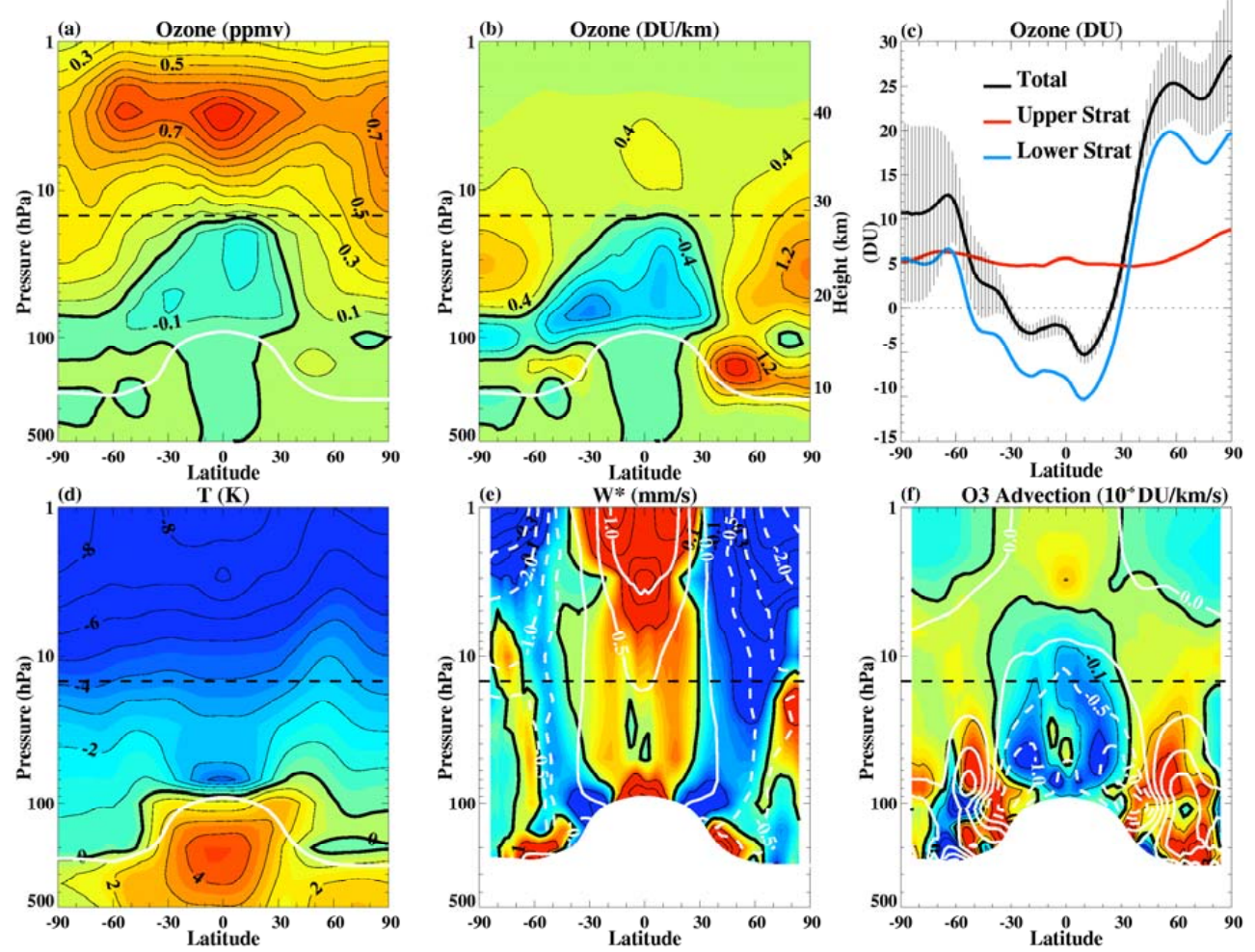

Fig. 3. Same as Fig. 2, but for simulation Cl60.

(100-200 days), and is 10 times shorter than the advective timescale at $10 \mathrm{hPa}$. Because of the longer advective timescale compared with the ozone photochemical lifetime above $10 \mathrm{hPa}$, strengthening of the Brewer-Dobson circulation has little effect on the upper stratospheric ozone.

Another approach to demonstrate ozone changes caused by GHG increase is to use the Cl60 simulation in which the halogen loading is fixed at 1960 levels. Ozone levels are higher in C160 than in FREF for the periods 1975-1984 and 2060-2069, especially in the Antarctic lower stratosphere, because of a higher halogen loading in FREF. However, the decadal differences in the stratospheric ozone, temperature, and mean transport between 2060-2069 and 1975-1984 in Cl60, which must be cased by climate change, are qualitatively very similar to those in FREF. Figure 3 displays these Cl60 decadal differences, and shows that FREF differences (Fig. 2) are very well reproduced in Cl60. These similarities include: small decrease in the tropical total ozone, significant increase in the extratropical ozone with a larger peak value in the $\mathrm{NH}$ than in the $\mathrm{SH}$, almost uniformly $6 \mathrm{DU}$ upper stratospheric ozone increase, enhanced tropical upwelling, and increased extratropical downwelling (except in the Arctic lower stratosphere and a band around $60^{\circ} \mathrm{S}$ ). The most notable difference between Figs. 2 and 3 is that Cl60 has a larger ozone increase in the Arctic lower stratosphere (Fig. 3c), which appears to be caused by a stronger downwelling in the $\mathrm{NH}$ in $\mathrm{Cl} 60$ (Fig. 3e-f). There are other quan- titative differences between Figs. 2 and 3, which are likely caused by different SSTs used in simulation of the recent past, difference in EESC, and model internal variability. The overall agreement between $\mathrm{Cl} 60$ and FREF results, however, strongly supports our interpretations of Fig. 2 as mostly attributed to climate change.

\section{Discussion and conclusions}

The GEOSCCM simulates EESC recovery to 1980 values in the 2060s. The decadal differences in the stratospheric ozone and dynamics between 2060-2069 and 1975-1984 are investigated to study how climate change affects the vertical and latitudinal ozone distributions. Model results project that the extratropical column ozone increases by up to $6 \%$ in the $\mathrm{NH}$ and $3 \%$ in the $\mathrm{SH}$, but the tropical column ozone remains about the same, albeit smaller, after the recovery of EESC. Ozone changes have very different latitudinal structure in the upper and lower stratosphere. The latitudinally uniform increase of $6 \mathrm{DU}$ in the upper stratospheric ozone is attribute to GHG-induced cooling that slows the ozone loss reactions. In the lower stratosphere, enhanced ozone advection due to a stronger Brewer-Dobson circulation results in decreases in the tropical ozone and increases in the extratropical ozone. In a global mean sense, however, circulation-induced lower stratospheric ozone tropical 
decrease and extratropical increase cancel out. Therefore the global mean total column ozone "super-recovery" of $5 \mathrm{DU}$ is due to GHG-induced upper stratospheric ozone increase. Comparison with fixed halogen experiment supports our interpretations that these differences can be largely attributed to GHG increase.

Eyring et al. (2007) investigated the evolution of stratospheric ozone in the 21st century projected by eleven CCMs. Most models examined in Eyring et al. (2007) project a "super-recovery" of extratropical column ozone when halogen concentrations return to 1980 values, which is attributed by Eyring et al. (2007) to mainly GHG-induced middle to upper stratospheric ozone increase. Using CMAM simulations, Shepherd (2008) first pointed out that transportinduced lower stratospheric ozone changes have a significant role in column ozone changes and result in a "dynamical super-recovery" of extratropical ozone, especially in the $\mathrm{NH}$ mid-latitudes. The 6\% (3\%) "super-recovery" of $\mathrm{NH}$ (SH) extratropical ozone in GEOSCCM simulations are in very good agreement with Shepherd (2008) when the different baselines used in these two studies are taken into account (Comments by T. G. Shepherd, 2009).

The GEOSCCM projection of circulation-induced tropical column ozone "sub-recovery" also agrees well with Shepherd (2008). In the tropics, the two major mechanisms through which climate change affect the stratospheric ozone, upper stratospheric cooling and strengthening of the BrewerDobson circulation, have opposite effects on ozone abundance. Similar to CMAM results, the GEOSCCM simulations show that the tropical lower stratospheric ozone decrease outweighs the upper stratospheric ozone increase. However, CCMs examined in Eyring et al. (2007) do not reach a consensus on the sign of tropical column ozone change in the post-CFC era.

Note that GEOSCCM and CMAM also have important differences regarding the recovery of global-mean total ozone. We found that tropical ozone decrease and extratropical ozone increase in the lower stratosphere cancel out and thus the upper stratospheric ozone increase, which is nearly constant with latitude, results in a "super-recovery" of global-mean total column ozone. On the other hand, Shepherd (2008) emphasized the cancellation between upper stratospheric increase and lower stratospheric decrease, implying a net ozone decrease in the lower stratosphere. It is possible these discrepancies could be accounted for, at least partly, by the different pre- and post-CFC baselines analyzed in the two studies (1975-1984 and 2060-2069 in this study versus 1960-1970 and 2070-2099 in Shepherd, 2008).

Despite some different conclusions, the results presented here and Shepherd (2008) indicate that circulation changes play a crucial role in ozone distributions in the post-CFC era. Then an important question arises: how confident we are of the model-simulated strengthening of the Brewer-Dobson circulation? Although CCMs reach a consensus that the Brewer-Dobson circulation strengthens with the increase of
GHGs, there are no direct observational evidences to support the model results. There are, however, indirect evidences based on observed latitudinal structure of temperature and ozone trend in the lower stratosphere to support an accelerated circulation (Thompson and Solomon, 2005, 2009). A very recent publication by Engel et al. (2009) is the first to provide long-term measurements that shows no obvious trend of the stratospheric age of air in the NH middle stratosphere in the last three decades, which is contrary to model simulations (Waugh, 2009). Results of Engel et al. (2009) are derived from very limited samples, have large uncertainty, and do not exclude a strengthening of the Brewer-Dobson circulation in the lower stratosphere, but they cast some doubt on models' ability to simulate future changes of the transport. The disagreement between model simulations and age of air measurements needs to be resolved in order to correctly interpret model projections of ozone recovery.

One interesting finding in this study is the interhemispheric difference in the changes of the Brewer-Dobson circulation and ozone advection. A close inspection of Fig. 2e-f reveals that the reduced downwelling and ozone advection at $60^{\circ} \mathrm{S}$ in the lower stratosphere appears to be caused, at least partly, by an equatorward shift of the locations of the maximum downwelling. This equatorward shift is associated with a narrowing of the tropical upwelling region. At $70 \mathrm{hPa}$, the turnaround latitudes (where the residual vertical velocity changes sign) in 2060-2069 are located 2 degrees equatorward of those in 1975-1984. It is not clear what causes the narrowing of the tropical upwelling. Whether these features are produced in other model simulations remains to be determined. The narrowing of the tropical upwelling could be reflected in the distribution of long-lived tracers, which could be used as another approach to assess models' ability in simulating past and future changes in the Brewer-Dobson circulation.

Acknowledgements. This research was supported by NASA's MAP program. We thank two anonymous referees and T. G. Shepherd for constructive comments.

Edited by: V. Fomichev

\section{References}

Austin, J. and Wilson, R. J.: Ensemble simulations of the decline and recovery of stratospheric ozone, J. Geophys. Res., 111, D16314, doi:10.1029/2005JD006907, 2006.

Barnett, J. J., Houghton, J. T., and Pyle, J. A.: The temperature dependence of the ozone concentration near the stratopause, Quart. J. R. Meteorol. Soc., 101, 245-257, 1975.

Butchart, N. and Scaife, A. A.: Removal of chlorofluorocarbons by increased mass exchange between the stratosphere and troposphere in a changing climate, Nature, 410, 799-802, 2001.

Butchart, N., Scaife, A. A., Bourqui, M., de Grandpré, J., Hare, S. H. E., Kettleborough, J., Langematz, U., Manzini, E., Sassi, F., Shibata, K., Shindell, D., and Sigmond, M.: Simulations of 
anthropogenic change in the strength of the Brewer-Dobson circulation, Climate Dyn., 27, 727-741, 2006.

Engel, A., Mobius, T., Bonisch, H., Schmidt, U., Heinz, R., Levin, I., Atlas, E., Aoki, S., Nakazawa, T., Sugawara, S., Moore, F., Hurst, D., Elkins, J., Schauffler, S., Andrews, A., and Boering, K.: Age of stratospheric air unchanged within uncertainties over the pat 30 years, Nature Geosci., 2, 28-31, 2009.

Eyring, V., Butchart, N., Waugh, D. W., Akiyoshi, H., Austin, J., Bikki, S., Bodeker, G. E., Boville, B. A., Bruhl, C., Chipperfield, M. P., Cordero, E., Dameris, M., Deushi, M., Fioletov, V. E., Frith, S. M., Garcia, R. R., Gettelman, A., Giorgetta, M. A., Grewe, V., Jourdain L., Kinnison, D. E., Mancini, E., Manzini, E., Marchand, M., Marsh, D. R., Nagashima, T., Newman, P. A., Nielsen, J. E., Pawson, S., Pitari, G., Plummer, D. A., Rozanov, E., Schraner, M., Shepherd, T. G., Shibata, K., Stolarski, R. S., Struthers, H., Tian, W. and Yoshiki, M.: Assessment of temperature, trace species, and ozone in chemistry-climate model simulations of the recent past, J. Geophys. Res., 111, D22308, doi:10.1029/2006JD007327, 2006.

Eyring, V., Waugh, D. W., Bodeker, G. E., Cordero, E., Akiyoshi, H., Austin, J., Beagley, S. R., Boville, B. A., Braesicke, P., Bruhl, C., Butchart, N., Chipperfield, M. P., Dameris, M., Deckert, R., Deushi, M., Frith, S. M., Garcia, R. R., Gettelman, A., Giorgetta, M. A., Kinnison, D. E., Mancini, E., Manzini, E., Marsh, D. R., Matthes, S., Nagashima, T., Newman, P. A., Nielsen, J. E., Pawson, S., Pitari, G., Plummer, D. A., Rozanov, E., Schraner, M., Scinocca, J. F., Semeniuk, K., Shepherd, T. G., Shibata, K., Steil, B., Stolarski, R. S., Tian, W. and Yoshiki, M.: Multimodel projections of stratospheric ozone in the 21 st century, J. Geophys. Res., 112, D16303, doi:10.1029/2006JD008332, 2007.

Garcia, R. R., and Randel, W. J.: Acceleration of the BrewerDobson circulation due to increases in greenhouse gases, J. Atmos. Sci., 65, 2731-2739, 2008.

Jiang, X., Eichelberger, S. J., Hartmann, D. L., Shia, R., and Yuan, Y. L.: Influence of doubled $\mathrm{CO} 2$ on ozone via changes in the Brewer-Dobson circulation, J. Atmos. Sci, 64, 2751-2755, 2007.

Jonsson, A. I., De Grandpre, J., Fomichev, V. I., McConnell, J. C., and Beagley, S. R.: Doubled $\mathrm{CO}_{2}$-induced cooling in the middle atmosphere: photochemical analysis of the ozone radiative feedback, J. Geophys. Res., 109, D24103, 2004.

Ko, M. K. W., Sze, N., and Weisenstein, D. K.: The roles of dynamical and chemical processes in determining the stratospheric concentration of ozone in one-dimensional and two-dimensional models, J. Geophys. Res., 94, 9889-9896, 1989.

Li, F., Austin, J., and Wilson, J.: The strength of the BrewerDobson circulation in a changing climate: coupled chemistryclimate model simulations, J. Climate, 21, 40-57, 2008.

McLandress, C. and Shepherd, T. G.: Simulated anthropogenic changes in the Brewer-Dobson circulation, including its extension to high latitudes, J. Climate, doi:10.1175/2008JCLI2679.1, in press, 2009.
Newman, P. A., Daniel, J. S., Waugh, D. W., and Nash, E. R.: A new formulation of equivalent effective stratospheric chlorine (EESC), Atmos. Chem. Phys., 7, 4537-4552, 2007, http://www.atmos-chem-phys.net/7/4537/2007/.

Oman, L., Waugh, D. W., Pawson, S., Stolarski, R. S., and Newman, P. A.: On the influence of anthropogenic forcings on changes in the stratospheric mean age, J. Geophys. Res., 114, D03105, doi:10.1029/2008JD010378, 2009.

Pawson. S., Stolarski, R. S., Douglass, A. R., Newman, P. A., Nielsen, J. E., Frith, S. M., and Gupta, M. L.: Goddard Earth Observing System chemistry-climate model simulations of stratosphere ozone-temperature coupling between 1950 and 2005, J. Geophys. Res., 113, D12103, doi:10.1029/2007JD009511, 2008.

Perlwitz, J., Pawson, S., Fogt, R. L., Nielsen, J. E., and Neff, W. D.: Impact of stratospheric ozone hole recovery on Antarctic climate, Geophys. Res. Lett., 35, L08714, doi:10.1029/2008GL033317, 2008.

Rosenfield, J. E., Douglass, A. R., and Considine, D. B.: The impact of increasing carbon dioxide on ozone recovery, J. Geophys. Res., 107(D6), 4049, doi:10.1029/2001JD000824, 2002.

Rosenfield, J. E. and Schoeberl, M. R.: Recovery of the tropical lower stratospheric ozone layer, Geophys. Res. Lett., 32, L21806, doi:10.1029/2005GL023626, 2005.

Shepherd, T. G.: Dynamics, stratospheric ozone, and climate change, Atmos.-Ocean, 46, 117-138, 2008.

Shepherd, T. G.: Interactive comment on "Stratospheric ozone in the post-CFC era" by F. Li et al., Atmos. Chem. Phys. Discuss., 8, S10712-S10715, 2009.

Thompson, D. W. J. and Solomon, S.: Recent stratospheric climate trends as evidenced in radiosonde data: global structure and tropospheric linkages, J. Climate, 18, 4785-4795, 2005.

Thompson, D. W. J. and Solomon, S.: Understanding recent stratospheric climate change, J. Climate, doi:10.1175/2008JCLI2482.1, in press, 2009.

Waugh, D. W., Oman, L., Kawa, S. R., Stolarski, R. S., Pawson S., Douglass, A. R., Newman, P. A., and Nielsen, J. E.: Impacts of climate change on stratospheric ozone recovery, Geophys. Res. Lett., 36, L03805, doi:10.1029/2008GL036223, 2009.

Waugh, D. W.: The age of stratospheric air, Nature Geosci., 2, 14 $16,2009$.

World Meteorological Organization (WMO)/United Nations Environment Programme (UNEP): Scientific Assessment of Ozone Depletion: 2006, World Meteorological Organization, Global Ozone Research and Monitoring Project, Report No. 50, Geneva, Switzerland, 2007. 